\title{
Elektroniska datu bāze nestandarta mēbelēm
}

\author{
Andra Ulme ${ }^{1}$, Kristīne Šuste ${ }^{2}$ \\ ${ }^{1,2}$ Dizaina tehnoloğiju institūts, Materiālzinātnes un lietiš̌şās ķı̄imijas fakultāte, R̄̄gas Tehniskā universitāte
}

\begin{abstract}
Kopsavilkums. Raksta mērķis ir iepaz̄̄stināt ar RTU maǵistra darba ietvaros projektēto elektronisko datu bāzi, tās struktūru un kategorijām, sniegt iespēju ikvienam interesentam iepazīties ar apkopoto informāciju par neparastas formas mēbelēm datu bāzes ietvaros, iepazīt sabiedrības aptaujas rezultātus. Tiek nodrošināta starpvalstu sadarbība. Ir ticis noskaidrots sabiedrības viedoklis par neparastas formas mēbelēm. Plānota datu bāzes demonstrēšana un testēšana.
\end{abstract}

Atslēgas vārdi: Neparastas formas mēbeles, mēbel̦u dizains, datu bāze, aptauja.

\section{IEVADS}

Dažādos laika posmos, attīstoties tehnologiijām, parādās arvien jauni materiāli, kas pakl̦aujas neparastu formu veidošanai. Neparastas formas parādās ēku celtniecībā un interjera dizainā; tas ietekmē mēbel̦u projektēšanu. Ierastās mēbelu formas tiek aizvietotas ar jaunām un vēl neredzētām, neparastām formām. Aktuāls ir jautājums par atšksirīgumu interjerā. Viens no veidiem, kā piešksirt interjeram individuālu raksturu, ir tajā izvietotās mēbeles neparastās formās.

Neparastu formu mēbel̦u klāsts ir samērā plašs. Konkrētas formas mēbeles atrašana var būt sarežǵīta, jo nav pieejama vienota informācija, kurā atrastos dažādu uzṇēmumu un dizaineru piedāvātās mēbeles.

Rakstam ir vairāki mērḳi un tiem pakḷauti uzdevumi:

- iepazīstināt ar maǵistra darba ietvaros projektēto datu bāzi, tās struktūru un kategorijām;

- sniegt iespēju ikvienam interesentam iepazīties ar apkopotu informāciju par neparastas formas mēbelēm;

- iepazīstināt sabiedrību ar apkopotajiem aptaujas rezultātiem par neparastas formas mēbelēm;

- izstrādātā datu bāzes shēma tiek izmantota datu bāzes izveidē.

Ir izmantotas gan kvalitatīvās metodes, kas l̦āva iepazīt respondentu viedokli un dokumentāciju par datu bāžu izveidi, gan neparastu formu mēbel̦u projektus, rasējumus, ražotāju piedāvājumus un citu svarīgu informāciju. Rakstā parādīts aptaujas rezultātu apkopojums, kurš tapis ar kvantitatīvo zinātniski pētniecisko metožu palīdzību, dati atainoti izmantojot grafo-analīiskās metodes.

Ir pieejamas atsevišksas mēbel̦u datu bāzes, kā, piemēram, Dizaina Katalogs un Architonic, bet lielākā daḷa uzṇēmumu un mēbel̦u dizaineru izstrādā savas mājas lapas, kas neveido pārskatāmu un vienotu sistēmu.

Tiek veidotas datu bāzes, kurās vienkopus ir apkopota informācija no dažādiem pasaules valstu uzņēmumiem, tādejādi sniedzot iespēju arhitektiem, dizaineriem un ikvienam interesentam àtrā un ērtā veidā atrast sev interesējošās preces un tās iegādāties.
Lai mēbeles ietilptu neparastu formu mēbel̦u kategorijā, tās tiek atlasītas pēc šādiem kritērijiem:

- tāds, kas ir reti sastopams, vērojams; tāds, kas atšksiras no kā pierasta, paz̄istama (1);

- par neparastām formām netiek uzskatītas pirmformas, tādas kā aplis, trijstūris un taisnstūris (2).

\section{DATU BĀZES NEPIECIEŠAMĪBAS PAMATOJUMS}

Lai pamatotu elektroniskās datu bāzes izveides nepieciešamību, tika veikta aptauja. Aptauja bija brīvi pieejama interneta vidē no 2015. gada 15. maija lìdz 2015. gada 1. oktobrim Google Forms, kā arī tika izsūtīti individuāli e-pasti. Kopā izsūtīja un izsniedza vairāk nekā 300 aptaujas anketas, no kurām šobrīd 100 ir aizpildītas. Aptaujā iegūtos rezultātus apkopoja un izdarīja secinājumus.

Pirmajā aptaujas dạ̦ā respondentiem uzdeva jautājumus, kuri palīdzēja raksta autoriem izsecināt, ko respondenti saprot ar vārdu ,neparasts”. Attiecīgi no iegūtajām atbildēm var secināt, kuras mēbeles ietilpst šajā kategorijā.

Otrajā aptaujas dạ̦ā bija sniegts raksta autoru paskaidrojums, kas šajā aptaujā ir domāts ar vārdu „,neparasts”, lai iegūtu precīzas respondentu atbildes.

Lai uzzinātu respondentu viedokli par to, kurai mēbel̦u grupai datu bāzē būtu jāpievērš vislielākā uzmanība tika uzdots jautājums, kura mēbel̦u grupa ikdienā tiek lietota visbiežāk (skat. 1. attēlu).

Bija iespēja atzīmēt vairākus atbilžu variantus. Visbiežāk lietotā mēbel̦u grupa ir sēdmēbeles, kam seko galdi un mantu glabātuves. 12 respondenti apgalvo, ka visas mēbelı grupas lieto vienlīdz bieži.

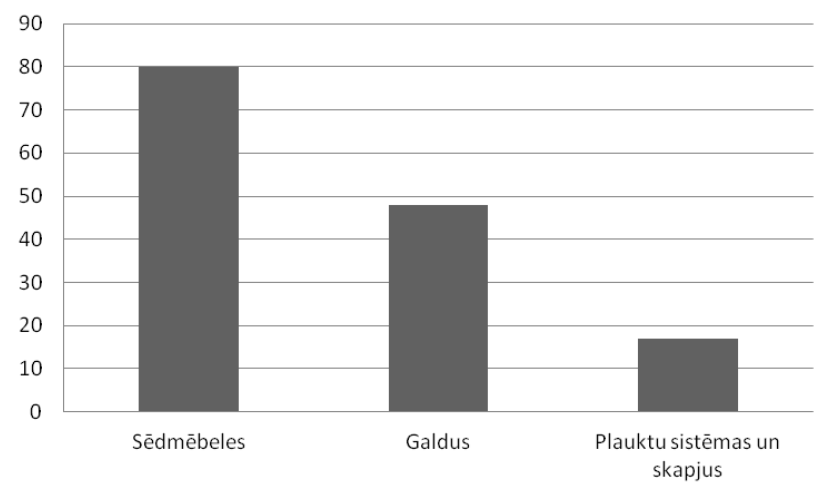

1. att. Respondentu atbildes uz jautājumu par ikdienā visbiežāk lietotajām mēbel̦u grupām.

Lai noskaidrotu, kādas formas mēbeles ir iekḷaujamas neparastu formu mēbel̦u kategorijāa, tika uzdots jautājums, kas tiek saprasts ar vārdu neparasts un kādas formas var uzskatīt par neparastām. Apkopojot iesniegtās atbildes secināts, ka respondentiem vārds "neparasts" saistās ar kaut ko reti sastopamu un neikdienišksu, tiek izmantoti šo vārdu sinonīmi. 
Respondenti uzskata, ka neparastas formas ir:

- asimetriskas;

- viḷnvveidīgas, nenoteiktas, dažādiem neregulāriem izliekumiem;

- visas formas, kas nav taisnstūrveida vai apl̦a forma;

- pirmformu savienojumi, kas ir taisnstūris, trijstūris un aplis.

Aptaujas rezultāti rāda, ka 55 no respondentiem ir saskārušies ar problēmu, ka interjerā nevar ievietot mēbeles to esošo izmēru dēḷ. Tas norāda uz to, ka dzīvojamās telpas ir l̦oti dažādas, un, iespējams, ir jāpiedāvā risinājums, kas ir piemērojams vairākām situācijām. 26 respondentiem nav bijušas šādas problēmas, iegādājoties mēbeles, 19 respondenti nav saskārušies ar šādu situāciju.

Ēkai piemērojamas mēbeles iegādātos izteikts vairākums respondentu (skat. 2. att.). Šāda veida mēbeļu klāsts ir pieprasīts, datu bāzē būtu pieejama kategorija „ēkai piemērojamas mēbeles".

Šìs kategorijas mēbeles ir unikālas ar to, ka ir piemērojamas dažādām ēkām, neatkarīgi no ēkas būvapjoma. Tādejādi nav jāveic individuāli pasūtījumi, lai mēbeli ievietotu vēlamajā vietā, kā arī mēbeli var iegādāties tūlītēji.

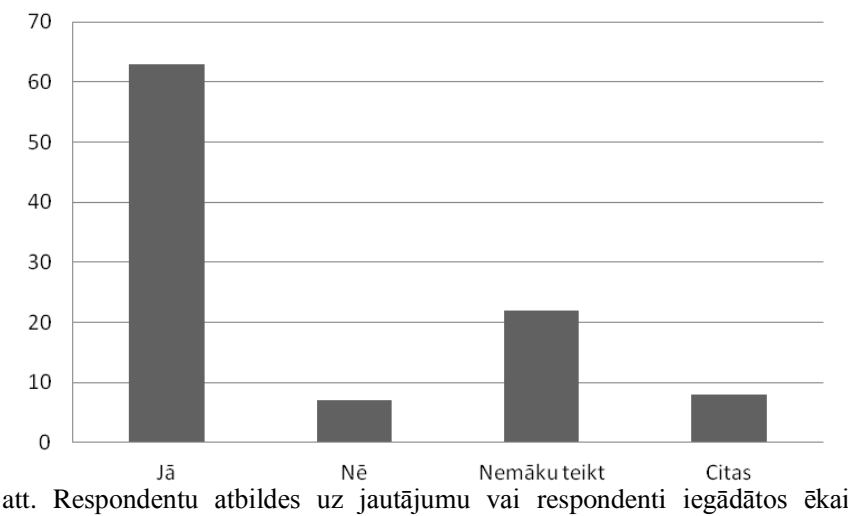

2. att. Respondentu atbildes uz jautājumu vai respondenti iegādātos ēkai piemērojamas mēbeles.

Lai noskaidrotu kāda daļa respondentu orientējas neparastu formu mēbelı klāstā, tika uzdots jautājums, kur šādas mēbeles var iegādaties (skat. 3. attēlu).

Bez sniegtajām atbilžu iespējām tiek minēti tādi piemēri, kā Martela, Edra, Trentini, Steelcase, R̄̄gas Krēslu fabrika; divi respondenti min dizaineri Jāni Straupi.

Citu atbilžu variantu izvēlas 30 respondenti, no kuriem vairāk nekā puse norāda, ka nezina, kur šādas mēbeles var iegādāties.

Pēc sniegtajām atbildēm var secināt, ka atsevišḳa cilvēku grupa izrāda interesi par šāda veida mēbelēm un spēj minēt konkrētus uzṇēmumus vai dizainerus, kas šādas mēbeles piedāvā.

Kā piemēri neparastu formu mēbelēm sabiedriskās telpās tiek minēti:

- bāri un restorāni - Yolo bārs, restorāni Dārzs, Il Patio, Mākonis un Garāža;

- augstskolas - Rīgas Tehniskā universitāte, Materiālzinātnes un lietišķās ķīmijas fakultāte, Latvijas Universitāte, Dabaszinātņu akadēmiskais centrs.

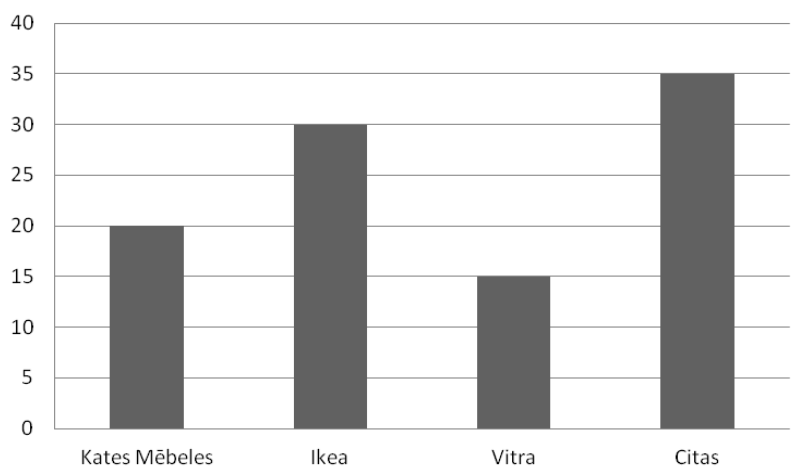

3. att. Respondentu atbildes uz jautājumu par to, kur iespējams iegādāties neparastas formas mēbeles.

Minētie piemēri laaj izvērtēt un izdarīt secinājumus par to, kādas formas tiek uzskatītas par neparastām. Pēc noteiktajiem kritērijiem, kādām mēbelēm būtu jāietilpst zem vārda neparasts, atsevišķas sabiedriskās telpas ar tajā esošajām mēbelēm neatbilst projekta autoru izvirzītajiem atlases kritērijiem.

Gandrīz visi respondenti atbild, ka ēkai piemērojamas mēbeles nav redzējuši. Tikai trīs cilvēki atminas, ka kaut kur šādas mēbeles ir redzējuši, bet nespēj minēt konkrētus piemērus.

Lai atrastu sev interesējošās mēbeles respondenti visbiežāk izmanto www.google.lv, kam seko tādi piemēri, kā www.architonic.com, www.dezeen.com, www.designboom.com, www.pinterest.com. Pārējie respondenti nevar nosaukt konkrētu datu bāzi.

Pēc respondentu atbildēm var secināt, ka konkrētu mēbel̦u datu bāžu lietošana viṇu ikdienā nav bieži sastopama, jo visbiežāk izvēlas izmantot tādu meklētājprogrammu kā www.google.lv. Kā arī pārējās minētās datu bāzes satur plašu informācijas daudzumu gan par mēbelēm un gaismas ķermeņiem, gan par dizaineriem, arhitektiem un utt. Lai atrastu sev interesējošās mēbeles, tiek ieguldīts liels laika patēriņš.

Pēc iegūtajām atbildēm var secināt, ka mēbeḷu datu bāzes netiek pietiekami reklamētas sabiedrības vidū, lai tās tiktu aktīvi izmantotas.

Neviens no respondentiem nespēj nosaukt nevienu datu bāzi, kurā būtu atsevišksa sadaḷa mēbelēm ar neparastām formām. Atsevišksi respondenti piebilst, ka ik pa laikam kādā mājas lapā redz šāda veida mēbeles.

Balstoties uz iegūtajām atbildēm, var secināt, ka neparastas formas mēbeles atrašana var sagādāt grūtības, jo nav izveidota vienota datu bāze. Grūtības sagādā arī tas, ka respondenti nezina kurā datu bāzē būtu vislabāk un ērtāk nepieciešamo meklēt.

Kā neparastu formu mēbeḷu dizaineri tiek minēti tādi dizaineri kā, piemēram, Karims Rašids, Patrīcija Urkiola, Filips Starks, Zaha Hadida un Maximo Riera, kas ir pasaulē ar saviem darbiem labi paz̄stami dizaineri un arhitekti. Viṇu darbu klāstā ir arī mēbeles ar neparastām formām.

No Latvijas dizaineriem tiek minēti Jānis Mežulis un vairakkārt Jānis Straupe. Lielākā daļa respondentu nevar minēt konkrētus dizainerus un vinu darbus.

Arhitekti, galdnieki, interjera un mēbel̦u dizaineri ir savas jomas profesionāļi, kas spēj labi orientēties mēbeļu 
piedāvājumu klāstā, tomēr, mēbel̦u klāsts ir loti plašs. Vairums respondentu paši interesējas par savas telpas apmēbelēšanas iespējām, informāciju meklējot internetā vai specializētos žurnālos un grāmatās (skat. 4. attēlu). Neparastu formu mēbeḷu datu bāze piedāvātu unikālas mēbeles telpas labiekārtošanai.

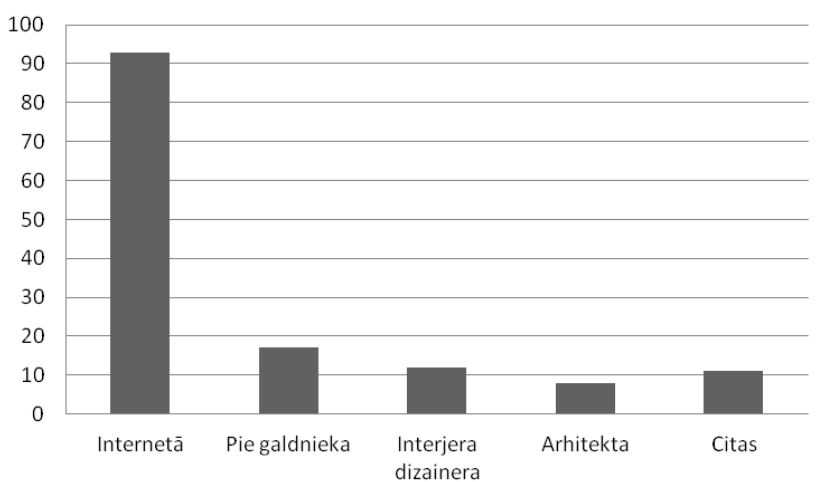

4. att. Respondentu atbildes uz jautājumu, kā parasti iegūst informāciju par telpas apmēbelēšanas iespējām.

Lai izveidotu orǵinālu interjeru, respondenti ir gatavi pasūtīt jebkuras funkcijas mēbeli, ja tā ir nepieciešama un atbildīs paredzētajam interjeram.

Izveidojot neparastu formu mēbel̦u datu bāzi, iespējams, liela daļa respondentu varētu atteikties no individuālas mēbel̦u pasūtīšanas, tā vietā izvēloties, pietiekami plašā klāstā esošās neparasto formu mēbeles.

\section{DATU BĀZES STRUKTŪRA UN TĀS KATEGORIJAS}

Latvijas Dizaineru savienība un Latvijas Republikas Kultūras ministrija ir organizācijas, kas rūpējas par dizaina un mākslas jautājumiem Latvijā. Š̄is organizācija sniedz daḷu no nepieciešamās informācijas datu bāzes izveidē, ir iespējams apzināt lielu skaitu Latvijā esošo dizaineru, līdz ar to iepazīties ar viņu darbiem.

Pēc šāda paša principa tiek iegūta informācija par neparastas formas mēbelēm Eiropas Savienībā un Amerikas Savienotajās valstīs.

Liela daļa mēbel̦u tiek atlasītas apmeklējot mēbel̦u ražotāju un dizaineru izveidotās datu bāzes.

Datu bāzes struktūra tiek veidota atbilstoši šādiem principiem:

- datu bāzes galvenās kategorijas, kam pakḷautas palīgkategorijas;

- sākotnēji zem katras kategorijas paredzēts vienāds skaits palīgkategoriju; palīgkategorijas tiek noņemtas, ja tajās nevar iekl̦aut atbilstošās mēbeles.

- ja galvenajā kategorijā ir tikai dažas mēbeles, tās netiek sadalītas pa palīgkategorijām.

Datu bāzes struktūra balstās uz trim galvenajām kategorijām, kas tālāk papildinātas ar palīgkategorijām. Trīs galvenās kategorijas veido: iekštelpu mēbeles, āra mēbeles un ēkai piemērojamas mēbeles. Katra galvenā kategorija tālāk iedalās atpūtas mēbelēs, galdos un mēbelēs lietu glabāšanai. Datu bāzes shēmu skat. 6. attēlā.

Tiks atspoguḷota informācija par konkrētu izstrādājumu:

1. mēbeles fotogrāfija;

2. dizainera vārds un uzvārds;

3. mēbeles izgatavošanas gads;
4. mēbeles apraksts;

5. informācija par dizaineri;

6. mēbeles izmēri;

7. mēbeles ražotāja vai dizainera logo un saite, kas datu bāzes lietotāju aizved tieši pie ražotāja, pie kura mēbeli var iegādāties.

Paraugu ar iekļauto informāciju par vienu mēbeli skat. 5. attēlā.

\section{SERIE UP 2000}

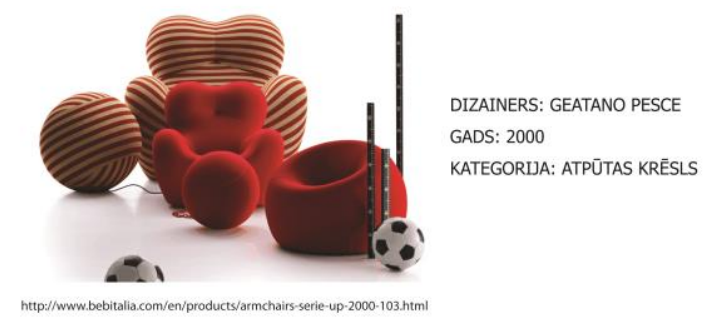

MĒBELES APRAKSTS:

Kolekcija izstrādāta 1969. gadā. Sērija "UP" ir viena no izcilākajām kolekcijām dizaina pasaulē. Atpūtas krēslam ir izteiktas, neparastas formas, kas apvilktas ar elastigu audumu. Sëriju kopā veido septinas preces.

GEATANO PESCE:

Dimis 1939. gadā Itälijā, studējis Venēcijā. Darbojies tādās jomās kā arhitektūra, interjera dizains, grafika, filmas utt. Realizējis vairākus projektus arhitektūrā tostarp Hubin apartamentus Parizē (1986), Sưmana rezidenci Nujorkă (1994), u.c. Arhitekts ir labi pazistams ar

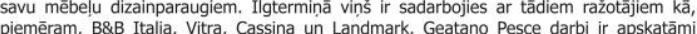

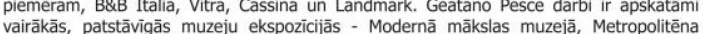
vairākās, patstāvigās muzeju ekspozicijas - Modernă mākslas muzejā, Metropolitēna mākslam muzejā Londonă, Pompidu centrā Parizē u.c.

IZMĒRI:

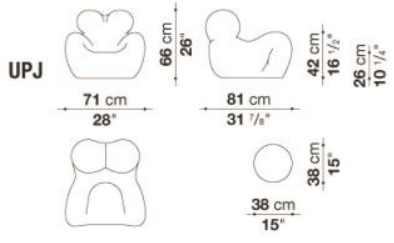

\section{B\&BB}

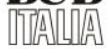

5. att. Paraugs - kartīte (4).

Datu bāze tiek izstrādāta divās valodās, latviešu un ang̣̣u valodā, tādejādi nodrošinot ērtu datu bāzes lietošanu Latvijas iedzīvotājiem un to, kainformācija ir pieejama internacionālā valodā.

Datu bāzē būtu pieejams meklētājs. Meklēšana notiktu pēc šādiem kritērijiem:

1. dizainera vārds un uzvārds;

2. mēbeles nosaukums;

3. izgatavošanas gads;

4. valsts nosaukums, kurā mēbele tiek ražota.

Balstoties uz pašlaik pieejamiem datiem datu bāzē, iekl̦autais minimālais mēbel̦u skaits būtu 350 mēbeles, prognozējamais apjoms līdz 2016. gada vasarai - 700 mēbeles ar visu klāt pievienoto informāciju.

Procesa gaitā tiks veikts arī eksperimentāls pētījums par datu bāzes darbību. Datu bāze tiks testēta viena mēneša garumā, kuras laikā raksta autori potenciālos datu bāzes lietotājus iepazīstinās ar tās saturu un iespējām. 
Datu bāzes testēšana ir paredzēta, lai noskaidrotu cik daudz potenciālo lietotāju apmeklēs datu bāzi un vai datu bāzē būtu nepieciešami kādi uzlabojumi.

\section{DATU BĀZES AIZSARDZĪBA}

Latvijas Republikas Ministru Kabineta autortiesību likums „Vispārīgie noteikumi” nr. 1 un 2 nosaka: ja radošās darbības rezultātā ir radies darbs, tad darba autoram ir tiesības aizsargāt savu darbu.

Šajā pašā likumā, ir noteikts, ka autortiesības pieder autoram, tiklīdz darbs ir radīts, neatkarīgi no tā vai darbs ir pabeigts. Neatkarīgi no darba uzdevuma un tā vērtības, kā arī izpausmes formas un veida.

Autora tiesības nosaka, ka autoram ir neatsavināmas tiesības uz autorību, darba atsaukšanu, darba neaizskaramību, vārdu, tiesības uz izlemšanu vai darbs tiks izziņots un kad tas tiks izzinots, pretdarbību pret sava darba sagrozī̌sanu, pārveidošanu vai sakropḷošanu. Arī tādai autora tiesību aizskaršanai, kas var kaitēt autora godam un cieņai. (6)

Likumā „Vispārīgie noteikumi” nr. 1 un 2 noteikts, ka autoram ir atsevišksas izṇēmuma tiesības uz datu bāzes izmantošanu. Autors var aţ̦aut vai aizliegt izplatît, publiskot vai demonstrēt datu bāzi, datu bāzi padarīt pieejamu, īslaicīgi vai patstāvīgi reproducēt, kā arī tulkot, adaptēt vai kādā citā veidā pārveidot.

Likums „Datu bāzes aizsardzības īpatnības” nr. 57 un 59 nosaka, ka par datu bāzes veidotāju uzskatāma fiziska vai juridiska persona, kura ir veikusi būtisku kvalitatīvu vai kvantitatīivu ieguldījumu un datu bāzes izstrādē ir uzņēmusies iniciatīvu vai ieguldījuma risku.

Šajā pašā likumā tiek minēts, ka datu bāzes izmantotājiem ir tiesības iegūt un atkārtoti izmantot nebūtiski kvalitatīvi vai kvantitatīivi novērtējamu datu bāzes satura daļu; tas attiecas uz datu bāzes daļu, kuru likumīgam izmantotājam ir aț̣auts iegūt un izmantot. Publiski pieejamās datu bāzes lietotāji nedrīkst veikt darbības, kas ir pretrunā ar datu bāzes izmantošanu un kas varētu aizskart datu bāzes veidotāja intereses.

Savukārt bez datu bāzes veidotāja piekrišanas var iegūt neelektronisku datu bāzes saturu personīgai lietošanai, daļu no datu bāzes satura izmantot izglītības vai zinātniskās pētniecības nolūkos, ja tiek norādīts avots, iegūt, kā arī atkārtoti izmantot valsts drošības nolūkos vai administratīviem un tiesvedības mērķiem (7).

Ministru kabineta notikumi ir izstrādāti, lai ikviens autors spētu aizsargāt savu radošo darbu, padarot to pieejamu plašam sabiedrības lokam, neliedzot iespēju iepazīties ar darba autora sasniegumiem, neatkarīgi no darbības jomas.

\section{KOPSAVILKUMS, IEGŪTIE REZULTĀTI}

Datu bāze būtu aktuāla gan mēbel̦u ražotājiem, gan interjera un mēbel̦u dizaineriem, gan arhitektiem un, protams, arī pašiem mēbel̦u pasūtītājiem.

Mēbel̦u piedāvājuma klāsts tiek vērsts uz māju īpašniekiem, lielu un mazu dzīvokḷu īpašniekiem, kas vēlas savā interjerā redzēt neparastas formas mēbeles. Mēbel̦u piedāvājuma klāsts parāda, ka ir padomāts arī par mazu dzīvokḷu īpašniekiem, kuriem ir iespējams iegādāties ēkām piemērojamas mēbeles, kas, iespējams, ir tiem aktuālākas nekā plašu dzīvokḷu ippašniekiem.

Attiecinot iepriekš apskatīto uz dažādām telpiskām formām, varam secināt, ka informācijas kvantitāte vispirms ir atkarīga no šo formu komplicētības un tā ir uztverama kā telpas attīstība laikā, un datu bāze ir kā laikmeta liecība.

N̦emot vēra latvisko individualitāti un reǵionālās īpatnības, jāsecina, ka mums patīk ļoti individuāli arhitektoniski interjeri privātajām telpām. Tādēḷ š̄is datu bāzes izveide ir nepieciešama.

Pieņemot koncepciju, ka informācija mūsu priekšstatiem sniedz arvien jaunus piedāvājumus, varam atzīt, ka jebkura signāla vērtībā ir saistīta ikvienam no mums ar visu negaidīto, iepriekš grūti paredzamo, citiem vārdiem sakot - oriǵinālo.

No aptaujā iegūtajiem rezultātiem var secināt, ka neparastu formu mēbel̦u datu bāze būtu nepieciešama. Konkrētā mēbel̦u kategorija tiktu apvienota vienā datu bāzē, atvieglojot orientēšanos plašajā mēbel̦u piedāvājumu klāstā.

Datu bāzes struktūra ir izveidota tā, lai tajā varētu viegli orientēties, iegūt izglītojošu informāciju par mēbelēm un to dizaineriem. Ikvienam lietotajam būs ērti uztvert un analizēt datu bāzē piedāvāto informāciju, jo tā tiek logiski strukturēta, par ko liecina 6. attēlā redzamā datu bāzes shēma. Tiek nodrošināta starpvalstu sadarbība, lai izveidotu vēl $\operatorname{lī} \mathrm{dz}$ šim nebijušu datu bāzi.

Autora tiesības uz datu bāzi aizsargā autortiesību likums, kuru nosaka Latvijas Republikas Ministru kabinets. 


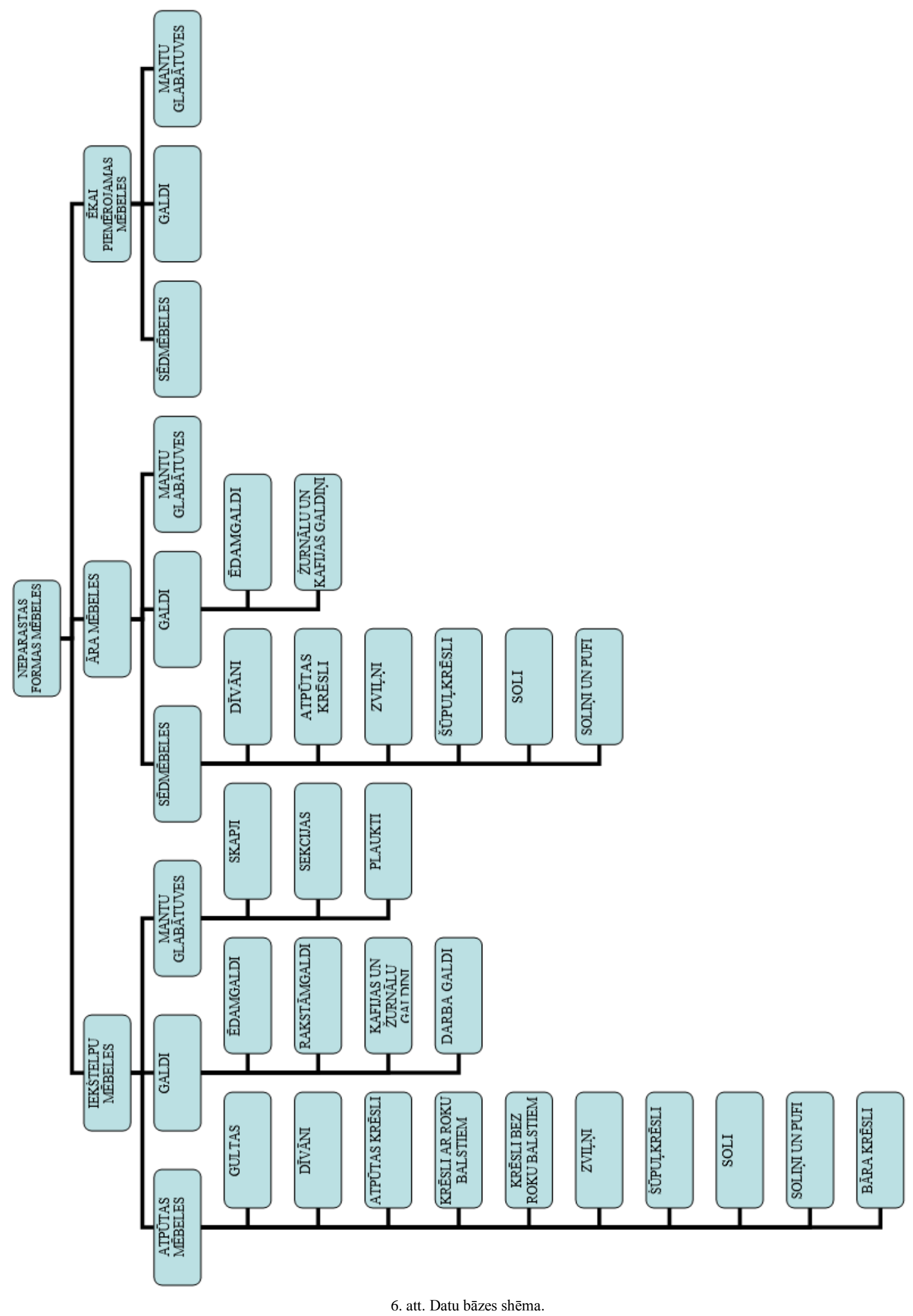




\section{LITERATŪRAS SARAKSTS}

1. Skaidrojošā vārdnīca Tezaurs.lv [tiešsaiste]. Skaidrojums vārdam neparasts, 14.12.2014. Pieejams: http://www.tezaurs.lv/sv/?w=neparasts

2. Ching, F. D. K. Arhitecture. Forms, Space and Order U.S. John Wiley \& Sons, Inc., 2007.

3. Strautmanis I. Dialogs ar telpu. Rīga: Liesma, 1977. 135 lpp.

4. B\&B Italia, Serie Up 2000 [tiešsaiste] 07.05.2015. Pieejams: http://www.bebitalia.com/en/products/armchairs-serie-up-2000-103.html

5. Autortiesību likums. Vispārīgie noteikumi. [tiešsaiste]. MK noteikumi Nr. 1, 2, 02.06.2015. Pieejams: http://likumi.lv/doc.php?id=5138

6. Autortiesību likums. Autora tiesības [tiešsaiste]. MK noteikumi Nr. 14 02.06.2015. Pieejams: http://likumi.lv/doc.php?id=5138

7. Autortiesību likums. Datu bāzes aizsardzības īpatnības [tiešsaiste]. MK $\begin{array}{lllll}\text { noteikumi } & \mathrm{Nr} . & 57, \quad 59, & 02.06 .2015 . & \text { Pieejams: }\end{array}$ http://likumi.lv/doc.php?id=5138

8. Par terminu mājaslapa un datubāze formas mainu. http://likumi.lv/doc.php?id=114590

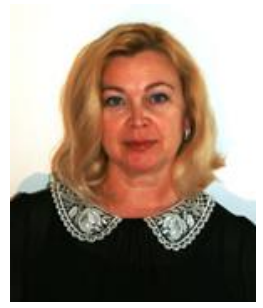

Andra Ulme, Dr. arch., Associated Professor, Riga Technical University, Faculty of Materials Science and Applied Chemistry, Institute of Material Technology and Design. Work experience: interior designer, interior architect, specializing in public and private interiors, specializing in hotel interior design, has completed more than 15 projects in suburbs over the last ten years, mostly in luxury style. Scientific activities: exploration of unutilized hidden resources and research of utilization possibility of these resources to promote of the development of national economy of Latvia

Address: Institute of Design Technologies, Riga Technical University, Kipsalas Str. 6, Riga, LV-1048, Latvia.

E-mail: andra.ulme@rtu.lv

Phone + 37167089256

Andra Ulme, Kristīne Šuste. Electronic Database for Non-Standard Furniture

The aim of this paper is to present an electronic data base, its structure and categories that are designed within the Master's thesis, to provide an opportunity for every person to get acquainted with the collected information in an electronic form and to introduce society to the extensive range of furniture that has an unusual form. International cooperation has to be provided to make an unprecedented data base. The database is created in Latvian and in English, so it could reach not only Latvian, but also international audience.

Quantitative and qualitative methods were used. A questionnaire was used to find out public opinion on unusually shaped furniture and interior applications. A database demonstration and testing is planned and improvements will be made if necessary. It is planned that the database will be passed on to users after testing it in the summer of 2016.

\section{Андра Улме, Кристине Шусте. Компьютерная база данных нестандартной мебели}

В научной статье представлены результаты исследований, которые велись в течение последнего года с целью изучить настроения общественности по ряду вопросов, связанных с созданием электронной базы данных нестандартных видов мебели. Цель данной статьи - ознакомить всех желающих с результатами и показать все аспекты необходимости такой базы данных как современного инструмента для специалистов и заказчиков

База данных создастся на латышском и английском языках, чтобы она была доступна не только для жителей Латвии. Так же широко используются международные контакты для получения данных об нестандартных видах мебели непосредственно от дизайнеров, производителей или владельцев таких экспонатов.

В статье авторы рассматривают актуальную тему о защите авторских прав и рассматривают отдельные статьи закона. Использована традиционная методика ведения научных расследований - информационно-теоретические и методологические начала, существенное внимание уделяется выявлению и анализу закономерностей, связанных с возникновением типовых ситуаций в ходе опроса населения и с помощью аналитических методов, авторы также представили результаты опроса.

В будущем планируется тестирование и демонстрация базы данных и дополнений к ней, а также улучшение базы данных, если таковое потребуется. Предполагается, что база данных будет доступна после тестирования, в начале лета 2016 года. 